\title{
Performance of wool type angora rabbits under temperate conditions of Kashmir (J\&K), India
}

\author{
Nafis I. Assad ${ }^{1}$, N. N. Khan ${ }^{2}$, Safeer Alam ${ }^{3 *}$ and Dibyendu Chakraborty ${ }^{4}$ \\ ${ }^{1}$ Frozen Semen Project, Department of Animal Husbandry, (J \& K), INDIA \\ ${ }^{2}$ Division of Animal Genetics and Breeding, FVSc, SKUAST-Kashmir(J \& K), INDIA \\ ${ }^{3}$ Extension (Trgs), SKUAST-Kashmir, Shalimar, Srinagar(J \& K), INDIA \\ ${ }^{4}$ Division of Animal Genetics and Breeding, SKUAST-J, Jammu (J \& K), INDIA \\ *Corresponding author. E-mail: safeeralam1@gmail.com
}

Received: April 15, 2016; Revised received: February 8, 2017; Accepted: May 7, 2017

\begin{abstract}
An attempt has been made to determine the production and quality performance of wool type Angora rabbits and screen out the best suitable breed under temperate conditions of Kashmir. A total of 202 records of French Angora and German Angora rabbit breeds maintained for 3 years (2009-2011) were evaluated to estimate the performance of quality and production traits in relation to genetic and non-genetic factors. For French Angora rabbits, the overall body weight gain (adult weight), annual wool yield (AWY), staple length (SL), medullation percentage (MP) and fiber diameter (FD) were found to be $2.506 \pm 0.0432 \mathrm{~kg}, 303.575 \pm 0.316 \mathrm{gms}, 5.161 \pm 0.0183$ $\mathrm{cms}, 2.228 \pm 0.0217 \%$ and $12.289 \pm 0.0178 \mu$, respectively. In case of German Angora rabbits, the values of 2.506 $\pm 0.033 \mathrm{~kg}, 605.96 \pm 0.474 \mathrm{gms}, 6.219 \pm 0.0279 \mathrm{cms}, 2.513 \pm 0.0348 \%$ and $12.347 \pm 0.0265 \mu$ were observed for the respective traits. The breed was found to reveal significant effect $(P<0.01)$ on birth weight, weaning weight, annual weight, annual wool yield, staple length and medullation percentage and non-significant effect on fiber diameter. The sex was found to exhibit non-significant effect on all the traits under study. Based on present study, it can be concluded that German Angora breed of rabbit is most suitable for angora wool production and quality under temperate climatic conditions of Kashmir region.
\end{abstract}

Keywords: Angora rabbits, Kashmir, Production performance, Temperate climate, Wool quality

\section{INTRODUCTION}

Angora rabbit wool is softer, silky and is eight times warmer than Angora sheep wool (Pokharna et al., 2004). Rabbit fur is widely used throughout the world. Angora wool is the third largest animal fibre produced, after sheep wool and mohair, with annual world production of about 8500 tons. Presently, China dominates the International Angora wool market and contributes about $90 \%$ to the total world production of Angora wool (Schlink and Liu, 2013). India is marginal producer of Angora wool with estimated annual production of about 30-40 tons. Angora wool production is the most important economic trait among Angora rabbits and appears to be affected by a number of genetic as well as non-genetic factors (Thebault et al., 1992; Katoch et al., 1999; Allain et al., 2004). Heritability estimates as genetic parameters for different wool traits in Angora rabbit are reported to be low to moderate (Allain et al.,2004). Further, wool traits could be improved by direct and indirect selection methods in Angora rabbits (Allain et al., 2004; Rafat et al., 2007). Initial wool clips have been found to be important in early selection due to their high genetic correlation with latter clips (Rafat et al.,
2009). Significant genetic correlation has been reported between wool yield and corresponding body weight in Angora rabbits (Garcia and Magofke, 2010; Singh et al., 2006). Likewise, correlated responses for body weight after selection for fleece yield in Angora rabbits have been observed experimentally (Qinyu, 2012). Present investigation was carried out to evaluate the performance of wool type Angora Rabbits under temperate conditions of Kashmir (J\&K), India.

\section{MATERIALS AND METHODS}

The data has been recorded over a period of three years (2009 to 2011) from the different breeds of rabbits maintained at Government Angora Rabbit Farm, Wusan- Pattan, District Baramulla, J\&K, India. The traits studied were body weight gain, annual wool yield, staple length, medullation percentage and fiber diameter. Temperature (maximum and minimum) and relative humidity were also recorded on monthly basis during the entire period of study (Table 1).

Mean, standard errors and coefficient of variations (CV) were computed statistically. The effects of genetic and non-genetic factors such as breed and sex on the growth parameters were analyzed by least square analysis using the technique developed by Harvey (1990). 
Table 1. Average temperature and humidity for the period of 2009-2011.

\begin{tabular}{lccc}
\hline \multirow{2}{*}{ Month } & \multicolumn{2}{c}{ Temperature } & Relative \\
\cline { 2 - 3 } & $\begin{array}{c}\text { Maximum } \\
{ }^{\circ} \mathbf{C}\end{array}$ & $\begin{array}{c}\text { Minimum } \\
{ }^{\circ} \mathbf{C}\end{array}$ & $\begin{array}{c}\text { Humidity \% } \\
\text { Hum }\end{array}$ \\
\hline January & 7.0 & -2.0 & 82 \\
February & 8.2 & -0.7 & 79 \\
March & 14.1 & 3.4 & 70 \\
April & 20.5 & 7.9 & 64 \\
May & 24.5 & 10.8 & 61 \\
June & 29.6 & 14.9 & 56 \\
July & 30.1 & 18.1 & 66 \\
August & 29.6 & 17.5 & 70 \\
September & 27.4 & 12.1 & 67 \\
October & 22.4 & 5.8 & 69 \\
November & 15.1 & 0.9 & 77 \\
December & 8.2 & -1.5 & 84 \\
Average & 19.7 & 7.3 & 70.4 \\
\hline
\end{tabular}

The following model was adapted in the present investigation with assumptions that the different components being fitted into the model were linear, independent and additive.

$\mathrm{Y}_{\mathrm{ijk}}=\square={ }_{, \mathrm{i}}+\mathrm{S}_{\mathrm{j}}+\mathrm{e}_{\mathrm{ijk}}$

Where, $Y_{i j k}=k^{\text {th }}$ record of individual of $i^{\text {th }}$ ram of $\mathrm{j}^{\text {th }} \operatorname{sex}$

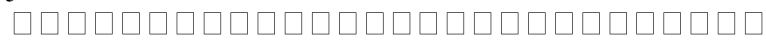

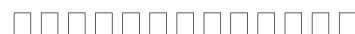

$R_{i}=$ Random effect of $i^{\text {th }}$ ram

$S_{j}=$ Fixed effect of $j^{\text {th }}$ sex

$\mathrm{e}_{\mathrm{ijklm}}=$ Error associated with each observation and assumed to be normally and independently distributed with mean zero and variance $\left(0, \sigma_{e}^{2}\right)$

\section{RESULTS AND DISCUSSION}

Growth performance: The least square means for birth weight (BT), weaning weight (WT) and annual weight gain (AwT) along with their standard errors are presented in Table 2. The average birth weight, weaning weight and adult weight were found to be $0.387 \pm$ $0.00698 \mathrm{~kg}$ (127), $0.964 \pm 0.00798 \mathrm{~kg}(127)$ and 2.506 $\pm 0.0333 \mathrm{~kg}$ (127), respectively for French Angora, whereas the value of respective traits were found to be $0.39 \pm 0.00893 \mathrm{~kg}(75), 0.961 \pm 0.0102 \mathrm{~kg}(75)$, and $2.519 \pm 0.0432 \mathrm{~kg}$ (75) for German Angora. Sivakumar et al. (2013) observed $0.5 \mathrm{~kg}$ birth weight and lower estimate of $0.6-0.7 \mathrm{~kg}$ weaning weight in Soviet Chinchilla breeds of rabbit. Lower estimate of 0.6-0.7 $\mathrm{kg}$ weaning weight and $1.8-1.9 \mathrm{~kg}$ adult weight were observed by Ghosh et al. (2008) in New Zealand White and Soviet Chinchilla breeds. On contrary, lower estimates of birth weight ranged from $0.3-0.4 \mathrm{~kg}$ and higher estimate of weaning weight from 2.1-2.2 were observed by Olonofeso et al. (2012) in three breeds of rabbit. The lower estimate of adult weight ranging from 2.2-2.5 kg were observed by Khalil et al. (2013) in Baladi Red and New Zealand White breeds of rabbit. Similar results of weaning weight from $0.7-1.3 \mathrm{~kg}$ were observed by Adelodun (2015) in four breeds of rabbit.

Breed was found to reveal significant effect $(\mathrm{P}<0.01)$ on birth weight, weaning weight and annual weight, but effect of sex was found to be non-significant on these traits. Similar findings of significant effect of breed on live litter body weight of Rabbit in Minna, Niger State, Nigeria were observed by Egena et al. (2012). Significant effect of genotype and nonsignificant effect of sex on individual kit weight in rabbit breeds and thier crosses were reported by Chineke (2005). On contrary, breed having nonsignificant effect on individual weaning weight on local rabbits of subtropical climate were reported by Ghosh et al. (2008).

Wool production performance: The least square means for annual wool yield (AWY), staple length (SL), medullation percentage (MP) and fiber diameter (FD) along with their standard errors are presented in Table 3. The average for annual wool yield (AWY), staple length (SL), medullation percentage (MP) and fiber diameter (FD) were found to be $303.575 \pm 0.316$ gm (127), $5.161 \pm 0.0183 \mathrm{~cm}(127), 2.228 \pm 0.0217$ percent (127) and $12.289 \pm 0.0178 \mu(127)$, respective-

Table 2. Least square means \pm SEM for growth parameters of wool type rabbit breeds (Sex- Wise Comparison).

\begin{tabular}{lcccccc}
\hline \multirow{2}{*}{ Traits } & \multicolumn{3}{c}{ French Angora } & \multicolumn{3}{c}{ German Angora } \\
\cline { 2 - 7 } & Male (72) & Female (55) & Overall (127) & Male (37) & Female (38) & Overall (75) \\
\hline BT (Kg) & $0.382 \pm 0.009$ & $0.393 \pm 0.010$ & $0.390 \pm 0.0089$ & $0.398 \pm 0.012$ & $0.383 \pm 0.013$ & $0.387 \pm 0.0069$ \\
WT (Kg) & $0.962 \pm 0.011$ & $0.966 \pm 0.012$ & $0.961 \pm 0.0102$ & $0.972 \pm 0.016$ & $0.951 \pm 0.013$ & $0.964 \pm 0.0079$ \\
AwT (Kg) & $2.517 \pm 0.044$ & $2.493 \pm 0.051$ & $2.519 \pm 0.0432$ & $2.497 \pm 0.062$ & $2.539 \pm 0.061$ & $2.506 \pm 0.033$ \\
\hline
\end{tabular}

Table 3. Least squares means \pm SEM for production traits of wool type rabbit breeds (Sex- Wise Comparison).

\begin{tabular}{lcccccc}
\hline \multirow{2}{*}{ Traits } & \multicolumn{3}{c}{ French Angora } & \multicolumn{3}{c}{ German Angora } \\
\cline { 2 - 7 } & Male (72) & Female (55) & Overall & Male (37) & Female (38) & Overall \\
\hline Annual wool yield (gm) & 303.583 & 303.564 & 303.574 & 605.838 & 606.079 & 605.958 \\
& \pm 0.412 & \pm 0.494 & \pm 0.453 & \pm 0.686 & \pm 0.663 & \pm 0.675 \\
Staple length (cm) & 7.103 & 6.024 & 6.564 & 6.192 & 6.245 & 6.218 \\
& \pm 1.111 & \pm 0.852 & \pm 0.9815 & \pm 0.038 & \pm 0.041 & \pm 0.395 \\
Medullation (\%) & 2.221 & 2.238 & 2.229 & 3.162 & 3.871 & 3.516 \\
& \pm 0.029 & \pm 0.033 & \pm 0.031 & \pm 0.692 & \pm 0.936 & \pm 0.814 \\
Fibre diameter $(\mu)$ & 12.288 & 12.291 & 12.289 & 12.341 & 12.353 & 12.347 \\
& \pm 0.024 & \pm 0.027 & \pm 0.025 & \pm 0.039 & \pm 0.036 & \pm 0.037 \\
\hline
\end{tabular}


ly for French Angora. The value of respective traits were observed to be $605.96 \pm 0.474 \mathrm{gm}(75), 6.219 \pm$ $0.0279 \mathrm{~cm}$ (75), $2.513 \pm 0.0348$ percent (75) and $12.347 \pm 0.0265 \mu(75)$ for German Angora. Similar findings with the values of $335.7 \pm 26.2 \mathrm{gm} \mathrm{AWY}$ in British Angora, $656.4 \pm 161.0$ gm AWY in Chinese Angora and higher estimate of $949.6 \pm 101.1$ gm AWY in German Angora were observed by Neupane et al. (2010). Higher estimates of $775.75 \pm 20.45$ gm AWY in German Angora were observed by Singh et al. (2006). No literature was found to estimate fiber diameter, staple length and medullation percentage in German and French Angora Rabbits. Breed was found to reveal significant effect on annual wool yield, staple length and medullation percentage, but has non- significant effect on fiber diameter. The effect of sex was found to be non-significant on annual wool yield, staple length, medullation percentage and fiber diameter. Similar results of significant effect of breed on wool production of different lines and strains of Angora rabbit were reported by Neupane et al. (2010). On the contrary, significant effect of sex on wool yield in Angora rabbit was reported by Sood et al. (2007).

\section{Conclusion}

The most common rabbit breeds in India as well in temperate Kashmir for Angora wool production are French Angora and German Angora and their production performance under different climatic conditions has to be ascertained by screen out the best suiting breed for the region for production and quality of angora wool. The German Angora breed of rabbits found to be best suited under temperate climate conditions of Kashmir valley of J\&K. The overall body weight gain in adult rabbits was $2.506 \pm 0.033 \mathrm{~kg}$ and the annual wool yield was $605.96 \pm 0.474$ gms with staple length of $6.219 \pm 0.0279 \mathrm{cms}$, medullation percentage of $2.513 \pm 0.0348 \%$ and fiber diameter $12.347 \pm 0.0265 \mu$ which is better than French Angora breed of rabbits. Based on present study it can be concluded that German Angora breed will be suitable for profitable wool production, and the findings will also help in further technology development and its transfer to the end users (farmers) in the region for successful rearing and maximizing income.

\section{REFERENCES}

Adelodun, O. F. (2015). Evaluation of post weaning morphometric traits among four breeds of rabbits in humid tropics. Global Journal of Animal Breeding and Genetics, 3: 2408-5502

Allain, D., Rochambeau, H. D., Thebault, R. G. and Vrillon, J. L. (2004). The inheritance of wool quantity and live weight in the French Angora rabbit. Animal Science, 68: 441-447

Chineke, C.A. (2005). Genetic and non-genetic effects on weaning and post weaning traits in rabbit breeds and thier crosses. Pakistan Journal of Biological Sciences,
10: $1402-1410$

Egena, S. S. A., Akpa, G. N., Alemede, I. C. and Aremu, A. (2012). Genetic and Non-genetic factors affecting litter size and birth weight of rabbit in Minna, Niger State, Nigeria. SSA Egena et al/Animal Production, 14(3):160166 , September 2012

Garcia, F. X. and Magofke, J. C. (2010). Genetic parameters for the production of fleece and body weight in Angora rabbits. Adv Prod Anim., 12: 81-90

Ghosh, S. K., Das, A., Bujarbaruah, K. M., Das, A., Dhiman, K. R. and Singh, N. P. (2008). Effect of breed and season on rabbit production under subtropical climate. World Rabbit Science, 16: 29-33

Harvey, W.R. (1990). User guide for LSMLMW and MIXMDL package mixed model least squares \& maximum likelihood computer programme. PC-2 version Mimeograph Colubia, Ohio, USA.

Katoch, S., Smbher, V. K., Manuja, N. K., Thakur, Y. P. and Gupta, K. (1999). Studies on genetic and phenotypic parameters for wool production traits in Angora rabbits. Indian Journal of Animal Research, 33: 126-128

Khalil, M. H. E., Owen, J. B. and Afifi, E. A. (2013). A review of phenotypic and genetic parameters associated with meat production traits in rabbits. Animal Breed Abstract, 54: 726-749

Neupane, D., Dhaubhadel, T. and Prashad, S. R. (2010). Evaluation of Wool Production Performance on Different Lines and Strains of Angora Rabbit at Khumaltar, Lalitpur. Nepal Journal of Science and Technology, 11: 83-86

Olonofeso, O., Adejuwon, A. J., Ademokoya, V. A. and Durosaro, S.O. (2012). Breeding and Productive Performance of Three Breeds of Rabbit in South-West Nigeria. Global Journal of Science Frontier Research Bio-Tech \& Genetics, 12: 0975-5896

Pokharna, A. K., Gupta, N. P., Patni, P. C., Arora, R. K. and Shakyawar, D. B. (2004). Processing of Angora Rabbit Wool and Cashmere Production \& Utilization. Pp. 16673. 25-26th September 2004. Manali (H.P.).

Rafat, S. A., Allain, D., Thebault, R. G. and Rochambeau, H. D. (2007). Divergent selection for fleece yield in French Angora rabbits: Non-genetic effects, genetic parameters and response to selection. Livestock Science, 106: 169-175

Qinyu, M. (2012). Studies on method of early selection and early mating in German Angora rabbits. Journal of Applied Rabbit Research, 15: 322-328

Schlink, A. C. and Liu, S. M. (2013). Angora rabbits: A potential new industry for Australia. RIRDC Publication No.03/014. RIRDC, Australia.

Singh, U., Sharma, S. R., Bhatt, R. S., Kumar, D. and Risam, K. S. (2006). Effect of shearing intervals on the growth and wool parameters of German Angora rabbits. Indian Journal of Animal Science, 76: 88-91

Sivakumar, K., Thiruvenkadan, A. K., Ramesh, S. K. V., Muralidharan, J., Anandha, P. S. D., Saravanan, R. and Jeyakumar, M. (2013). Analysis of production and reproduction performances of soviet chinchilla and white giant rabbits in tropical climatic conditions of India. World Rabbit Science, 21: 101-106

Sood, A., Gupta, K., Risam, K. S., Katoch, S. and Kaila, O. P. (2010). Non-genetic factors affecting wool yield in angora rabbits. Indian Journal of Animal Research, 41 
Nafis I. Assad et al. / J. Appl. \& Nat. Sci. 9 (2): 1022 - 1025 (2017)

(3): 0367-6722

Thebault, R.G., Vrillon, J.L., Allain, D., Fahrat, E., Rochambeau, H. and Rochambeau, H. D. (1992). Effect of non-gentic factors on quantitative and qualitative features of Angora wool production at French farms. Journal Applied Rabbit Research, 15: 1568-1575 